Vol. 6, No. 1, 2020

Viktor Proskuryakov

\title{
DESIGNING THE ARCHITECTURE OF THE FIRST UKRAINIAN NATIONAL THEATER PAVILION FOR THE WORLD EXHIBITION
}

\author{
Professor of the Department of Architectural Environment Design \\ Lviv Polytechnic National University, Lviv \\ e-mail: Viktor.I.Proskuriakov@1pnu.ua \\ orcid: 0000-0003-1022-8984
}

Received: 24.04.2020 / Revised: 01.06.2020 / Accepted: 01.06.2020

(C) Proskuryakov V., 2020

https://doi.org/10.23939/as2020.01.120

Abstract. The paper presents the design search for the architecture of the Ukrainian pavilions for world theater forums and, in particular, the design decision for the architecture of the First Ukrainian National Theater Pavilion at the Prague Quadrennial 2019.

Key words: architectural idea, theatrical exhibition pavilions, the Prague Quadrennial.

\section{Problem statement}

The organizers of the Prague Quadrennial 2015 granted the status of "National" in section "Education" to a joint exhibition of the works by a world-renowned set designer Ye. Lysyk and the projects and realizations of theatrical spaces, premises, buildings, etc., developed by the students, doctoral students, and professors of the Department of Architectural Environment Design of Lviv Polytechnic National University. The participants from Lviv realized that further important steps awaited the Department. The exposition of the Department in Kafka's House, in which the organizers of the fourth Quadrennial housed the Ukrainian exhibition in 2015, became popular with the visitors of the Quadrennial and the theater professionals from all over the world. That is what influenced the decision of the organizers to invite the Department as the representatives from Ukraine to participate in further events of the Prague Quadrennial. Thus, the first exhibition of 2015 at the world theater forums for the period of Ukraine's independence has allowed us to present the achievements of Ukrainian theatrical art, theatrical technique, technology, set design, architecture and acting not only in Prague, but also at similar forums in Edinburgh (Scotland), Avignon (France), Taipei (Taiwan). It should be stressed that such exhibitions require special spaces, in other words, architectural objects, pavilions for displaying theatrical achievements not only in individual exhibition sections (for instance, education), but at the national level as a whole.

\section{Analysis of recent research and publications}

The Department of Architectural Environment Design of the Institute of Architecture of Lviv Polytechnic National University is probably the only department in Ukraine and Eastern Europe which devotes a special attention to scientific studies, teaching, research and applied design of theatrical architecture and set design. This is evidenced by a seminal dissertation of Professor V. Proskuryakov (Proskuryakov V. I., 2002, 755 s.), who is a founder of the Department, and the dissertations of his students B. Hoy (Hoy B. V., 2006, 20 s.), Z. Klymko (Klymko Z. V., 2019, 232 s.), I. Humennyk (Humennyk I. V., 2019, 20 s.), dedicated to various architectural aspects of theater and performance spaces and constructions. An array of dissertations and 
scientific publications of students and researchers of the Department addressed specific aspects of theatrical art, namely technologies, materials, technical tools, theory, philosophy of art - M. Yatsiv (Yatsiv M. B., 2002, $173 \mathrm{~s}$ ), S. Ivanov-Kostetskyy (Ivanov - Kostets'kyy S. O., 2011, s. 12-19), O. Kordunyan (Kordunyan O. P., 2009, 22 s), R. Kubay, I. Kopylyak, T. Harashchak (T. Harashchak, 2017, p. 58.), Y. Filipchuk (Yu. Filipchuk., 2017, s. 56-66.), (Z. V. Klymko, 2014, s. 63-74), (Yu. Filipchuk, 2018, s. 64-67), (Proskuryakov O. V., 2009, 20 s.), and, in particular, the phenomenon of set design was studied by Z. Klymko (Z. Klymko, 2016, s. 56-65) and K. Yanchuk (K. Ianchuk, 2015, p. 136-147). The researchers gained the experience in designing theater and performance stationary, landscape, mobile, demountable, transformed spaces; cultural and educational spaces, namely museums, cinemas, exhibitions, clubs, houses of societies; various entertainment spaces and others. But this was not enough to create the architecture of the future Ukrainian National Theater Pavilions, which are spatial construction of a new architectural type, ideologically grounded on the Ukrainian culture and allowing the integration of theatrical, performance, cultural and educational functions using modern technical and technological equipment.

\section{Objective of the article}

The paper aims to shed light on the design search for the architecture of the Ukrainian National Theater Pavilions for the world exhibitions and, in particular, the idea of the architectural design and construction of the First Ukrainian National Pavilion for the Prague Quadrennial 2019, designed at the Lviv Architectural School.

\section{Results and discussions}

The organizers of Prague Quadrennial 2015 taking into account the high level of the exposition presented by the Department of Architectural Environment Design invited its authors and organizers to participate in the next one in 2019 but under different circumstances and conditions. The fact is that there was a fire in the main exhibition building of the Industrial Palace in Fucik Park, where the Prague Quadrennial always took place in the past, and its left wing burnt down. The hosts of the Quadrennial failed to complete major renovation and restoration work which the building required before the PQ 2015 opening. The premises of Kafka House and the halls, the lobbies, the courtyards of some museums, and other cultural and educational buildings in the center of Prague became temporary sites of various sections of national expositions. However, the mini-sections were mostly located on different floors and the mansard of Kafka House. Participating for the first time in such a grand world scale event as the Prague Quadrennial, the designers of the Ukrainian exhibition from the Architectural School of Lviv Polytechnic were completely satisfied with the modest parameters of the exhibition spaces $(4.60 \times 3.60 \mathrm{~m}$ and the height of $3.37 \mathrm{~m}$ ). They implemented the idea of designing the exposition as a stage of the "theater" of kinetic projections of the works of the brilliant Ukrainian artist Ye. Lysyk - kinetic projections and sketches of performances, models, hangings, pallets, horizons, fragments of real performances created by the master, as well as various architectural objects designed by the students and professors of the Department, which were designed between 2010 and 2015. According to the designers' interpretation, the section represented a stage where the tablet was a floor, the horizon was one of the walls of the building, which occasionally was used as the screen for projecting the master's works and the projects and realizations by the authors of the Lviv Department and colleagues from a joint seminar on architectural and scenographic issues from Ryerson University, Toronto (Canada), under the supervision of Professors P. Bosyy and Sh. Dolgoy. The portal, side scenes and curtains of the "stage" were the prints of Lysyk's works and the researchers and the students of Lviv Architectural School (Klymko Z. V., 2015, s. 57-67) (Fig. 1).

However, the experience gained was of little use in creating an exposition space for the 2019 Quadrennial. There were several reasons for that. First, before the opening of the PQ 2019, it was planned to complete the restoration work on the premises of the main exhibition building, which was affected by 
the fire. The organizers, led by Pavlina Sulkova, decided to return to the presentation of exhibitions in exhibition pavilions, as it was done from the very beginning of the PQ in 1967 and all the following years until the fire. Professor P. Bosyy, who was the coordinator of the First Ukrainian National Exhibition at the Prague Quadrennial in 2019, decided that a pavilion would be designed and made by the specialists from the Department of Architectural Environment Design of Lviv Polytechnic National University.

Such a task was completely new for the faculty and the students of the Department as such spaces also should present scenographic works in real dimensions, whose authors have different views on the phenomenon of scenography (Hovard Pamela, Drabek Pavel, 2019, p. XX-XXIV). Therefore, it was decided to begin the design search for the architecture of the object long before June 2019, when the PQ 2019 was due to begin. The investigation started in students' semester projects, Bachelor and Master theses. Searching for a suitable design decision for the architecture of the future pavilion, the designers constantly monitored the ideas of the architecture of the pavilions and spaces of the previous PQs and of the events which exhibit presented the Ukrainian theatrical culture in the works of stage artists and theater architects in independent Ukraine and earlier when artists and architects from Ukraine participated in the Triennial of scenography in Riga and Vilnius, Moscow and Leningrad exhibitions "Outcomes of the season", such the exhibitions as "Theatrical artists of Georgia", "Theatrical artists of Siberia", "Artists of theater and cinema". Yet, first and foremost, the concepts of national theater pavilions at the Quadrennial exhibitions were explored.

Among the projects of the students of the Department, namely V. Lilyk, V. Savina, V. Madyar, M. Korovaynyk, O. Sekeresh, T. Horodchuk, O. Kotous, N. Duda and others supervised by Professor V. Proskuryakov, and the faculty members K. Yanchuk, Z. Klymko, Y. Filipchuk, there were many interesting works. The student V. Lilyk designed a 5x5 m square in the PQ 19 Main Palace, where the organizers planned to house the pavilions, an amphitheater-ramp, and a semi-circular backstage, fenced off from the amphitheater with semi-transparent backdrops. They can be used as screens for kinetic projections of performances, lightand-dark, and slide projections of scenographic works and horizon for the events that will take place in the center of the amphitheater-ramp (Fig. 2).
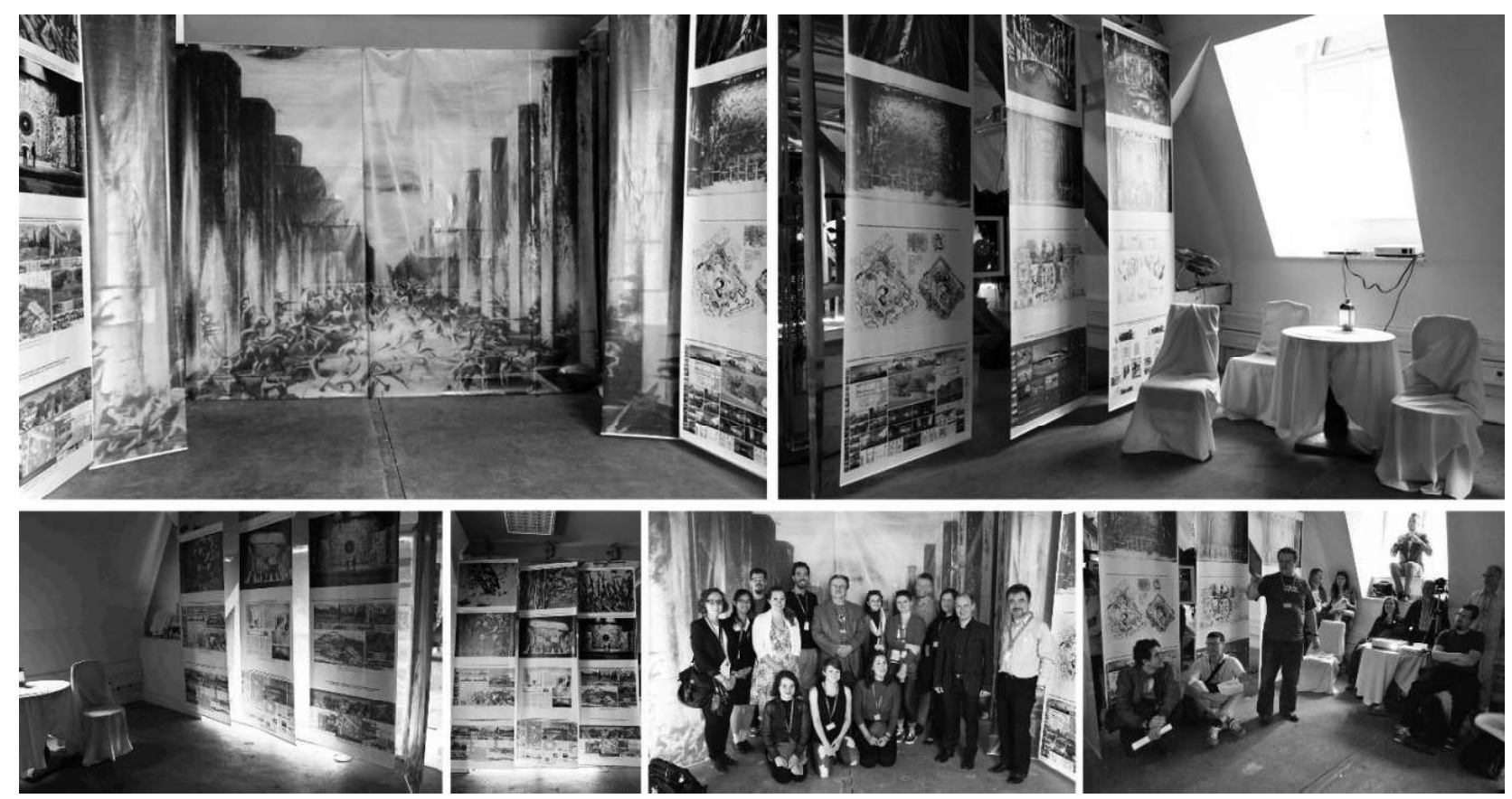

Fig. 1. Exposition of the Ukrainian exhibition in the section "Education" at the PQ15 as the "theater" of kinetic projections of the works by Ye. Lysyk and architectural objects designed by the students and professors of the Department of Architectural Environment Design between 2010 and 2015. (AED Department Archive) 

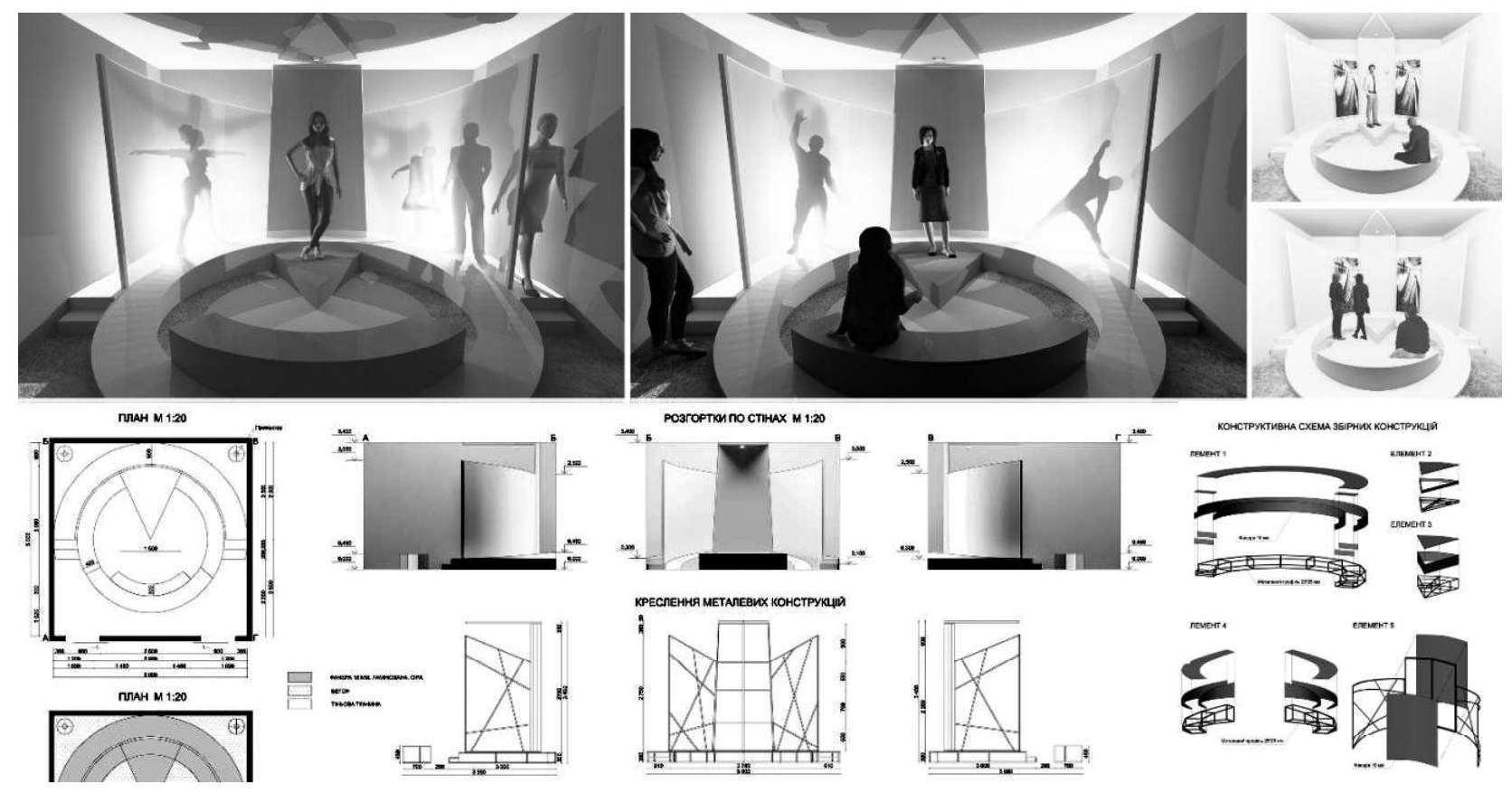

Fig. 2. Sketch design of the Ukrainian theater pavilion designed by the student V. Lilyk. (AED Department Archive)

The idea of the space design, the organization of acting, and the aesthetic design of the pavilion's architecture was suggested by the date of the Quadrennial in Prague, which was June 6-16. The 2019 Prague Quadrennial was to take place on the eve of the most mystical Ukrainian pre-Christian holiday called Kupala, celebrated on the evening of June 23, at night June 23 - June 24 and June 24. In ancient times, the natural landscapes of forests, fields, mountains were spaces of magical ritual actions, ritual plays of the ancient Slavs, including Ukrainians. The objects of worship in these rites were springs, rivers, swamps, lakes, ponds, and also the fire - in the cults of the celestial powers, and groves, forests, individual trees, and seasons of the year that symbolized the vegetative natural power. Later the acting that can and should be regarded as the Ukrainian pretheatre called the Kupala drama emerged. At that time, during the ancient Slavic holidays in prayers, the first principles of spatial arrangement and location of the spectator-participant and participant of the act concerning the act itself began to form. Ancient Ukrainian holidays were so widespread and integrated with all nature around settlements that it is almost impossible to find a place for ancient dances, Kupala bonfire and drama, sacrifices to the water, and various plays. It is assumed that the first constructions with fixed spaces of the Ukrainian pre-theater and theater and performance activity were ancient settlements, chapels, complexes, and temples. It is not only because in many cases the purpose of these structures has not been fully defined by renowned scientists and archaeologists (Kolchin B. A., 1985, s. 431), (Filipchuk M., 1998, c. 80-104), (Rusanova I. P., Timoshchuk B. A., 1993, s. 7, 9, 11, 18, 19, 20-29) and they are interpreted as spaces for a broad functional genre including prayers and plays. It is also because they contain some elements of architectural and spatial organization, elements of constructive decisions, zoning, and take into account certain physical conditions, which are also present in modern architectural and theatrical experience. The importance of the Kupala Drama for Ukrainian theater is crucial not only because it is considered to be the most perfect drama from the period of the Ukrainian pre-theater to the times of the Ukrainian ancient ceremonial theater, but also because it is filled with elements of acting, and most importantly because special spaces were built for it.

The verbal description of the structure of the "Kupala Theater", which has survived to our times, can be interpreted as follows: "The space for the performance of the Kupala drama structurally, spatially and functionally resembles both the ancient Slavic playground and the ancient Greek theater. The main structural materials of the "theater" were trunks and tree branches. Outside the village, four trees were dug in in the center of the lawn in the form of rectangular and the fifth largest one was set at the intersection of its diagonals. All around these trees the "amphitheater" was built of wooden logs on the piles dug into the ground in the form of a huge wreath with aisles. Later, boards for seats appeared on the logs. The elderly, the infirm, and children took the seats on the amphitheater. All the others participated in the performance. 
At the beginning of spring 2019, Professor V. Proskuryakov reconstructed the general appearance of the "Kupala Theater" space, its main components and then, based on them, made sketches of drawings that became part of the architectural and spatial design of the First National Ukrainian Pavilion, selected modern materials for elements, agreed on the scale of the pavilion with the space parameters in the Industrial Palace set by the organizers of the PQ. (Fig. 3) The senior students V. Vovk and A. Otkydach assisted in organizing sketches and making draft drawings of the pavilion. The students M. Loposh and Yu. Cholavyn made a large-scale model layout.

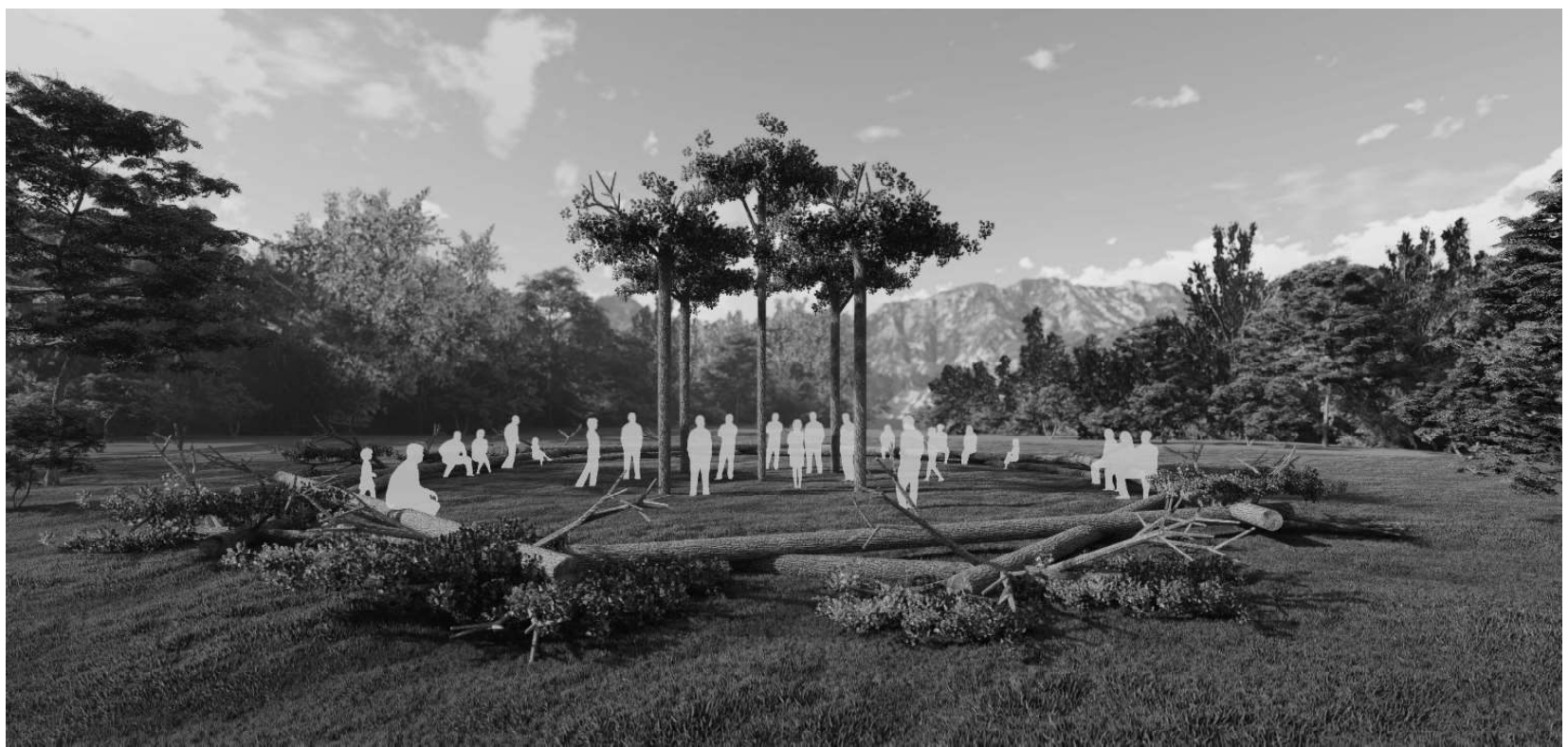

a

Розріз 1-1 M 1:50

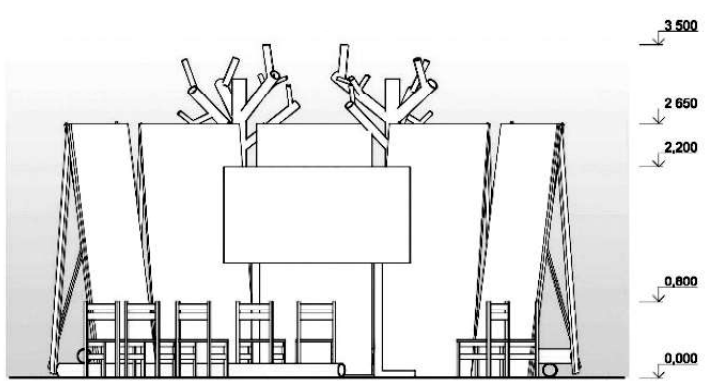

Пошук композиційного рішення
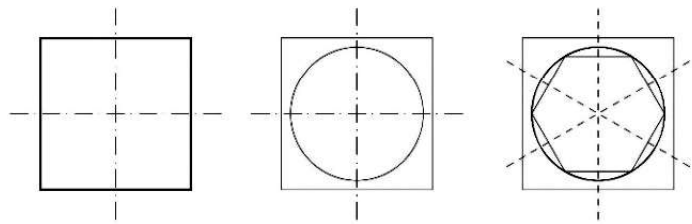

П^ан М 1:50

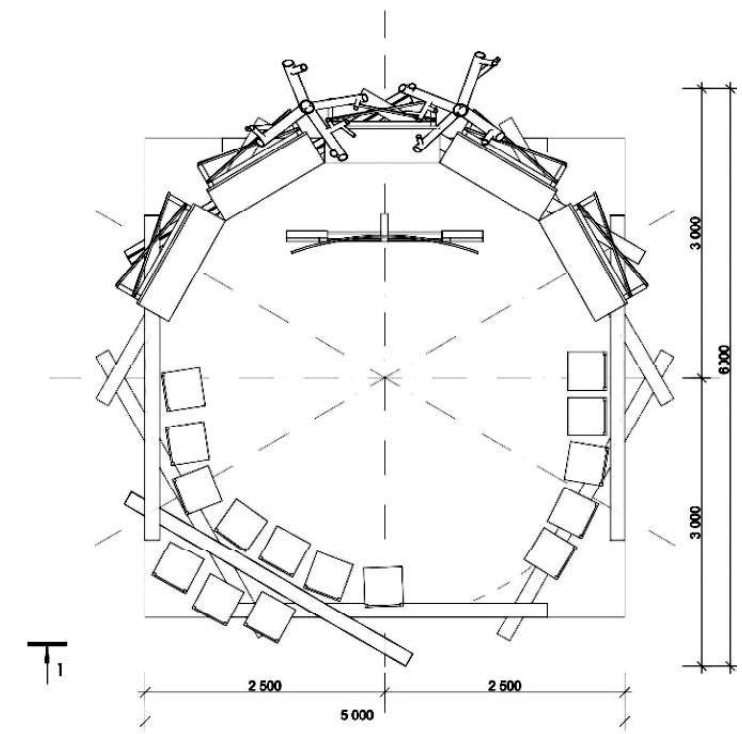

Fig. 3. Reconstruction of the general layout of the Kupala Theater space (a) by Professor V. Proskuryakov and sketches of the main drawings (b). (Professor V. Proskuryakov's Archive)

Eventually, the spatial design of the pavilion took the form of a double hexagon of pipes $\varnothing 20 \mathrm{~cm}$, which symbolized logs laid one on one in the marks of the floor of the palace displaced relative to each other and fitted into a circle (symbol of eternity) in a square of size $5 \times 5$ meters (the space allocated by the organizers for the exhibition). 
On one side of the main transverse axis of the space, the amphitheater of chairs (seats) above the "logs" pipes - was built. On the other side, space was crowned by a horizon copied from a majestic sketch of set design by a prominent Ukrainian artist Ye. Lysyk made for the folk opera "When the Fern Flowers" by Ye. Stankovych, for the Ukrainian folk choir named after I. G. Viriovky in 1978. This sketch of the master depicted not only the Kupala festival in all its glory - roundelays, plays, worships, but also the space of the "theater" of the Kupala drama.

The horizon, according to the designers, was to be attached to the spatial structures made of five tablets arranged in a semicircle, the task of which was to draw visitors into the depths of the Kupala Drama Theater created by Lysyk and also to separate the space of the pavilion from the mega-space of the exhibition hall (Fig. 4). Not many technical means were used; they included a set of acoustic and lighting equipment, a television screen for showing fragments of performances and all other theatrical events that took place in Ukraine from 2015 to 2019, performances and events held in the First National Ukrainian Theater Pavilion at the PQ 19.

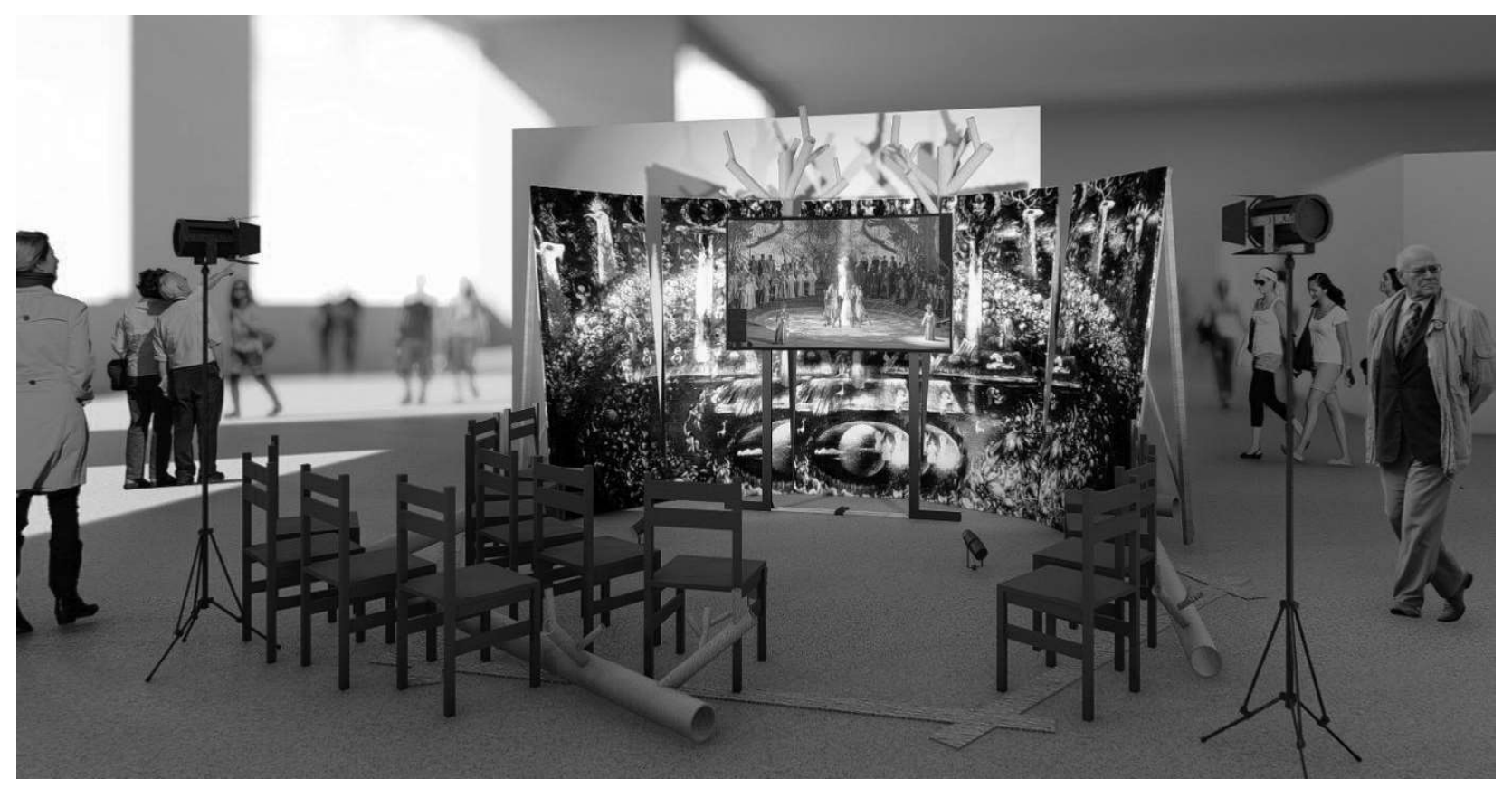

Fig. 4. The proposal for the final space design, the organization of acting and their aesthetic design using horizon-panorama with a copy of the set design sketch by the artist Ye. Lysyk made for the folk opera "When the Fern Flowers." (Professor V. Proskuryakov's Archive)

\section{Conclusions}

To successfully demonstrate the achievements of the masters of scenography and architecture of Ukrainian and world theater at exhibition events, it is not enough to use the traditional experience gained for showing the level of other arts.

Taking advantage of the invitation from the organizers of the Prague Quadrennial 2019, the team who designed the architecture of the First Ukrainian National Theater Pavilion implemented the idea of the space design, the organization of acting and their aesthetics, which connected the phenomenon of the theater with the past, the future, and the present. The theater pavilion was viewed as a synthesis of three components of the phenomenon of the theater: the phenomenon of man, the phenomenon of play, and the phenomenon of space.

The pavilion was delivered and assembled in Prague in the Industrial Palace on June 6 and left the Quadrennial on the evening of June 16, 2019 (Fig. 5).

\section{References}

Proskuryakov V. I. 2002. Pryntsypy rozvytku arkhitekturnoyi typolohiyi Ukrayins'koho teatru: dys. doktor arkh.:18.00.02. Kyyiv. 755 s. 
Hoy B. V. 2006. Arkhitektura yevreys'kykh teatriv Ukrayiny. Pryntsypy typolohiyi ta proektuvannya: avtoreferat dys. kand. arkh.: 18.00.02. L'viv. $20 \mathrm{~s}$.

Klymko Z. V. 2019. Arkhitektura stsenohrafiyi Ye. Lysyka: dys. kand. arkh.: 18.00.01. L'viv. $232 \mathrm{s.}$

Humennyk I. V. 2019. Rozvytok arkhitekturnoyi typolohiyi landshaftnykh teatriv v Ukrayini: dys. kand. arkh.: 18.00.02. L'viv. $20 \mathrm{~s}$

Yatsiv M. B. 2002. Arkhitekturno - prostorova orhanizatsiya svitlovoho seredovyshcha ukrayins'koyi tserkvy: dys. kand. arkh.: 18.00.01. L'viv. $173 \mathrm{~s}$.

Ivanov - Kostets'kyy S. O. 2011. Futurystychnyy dyzayn yak instrumentariy prohnozuvannya maybutn'oho. Arkhitektura: Visnyk NU,L'vivs'ka politekhnika“. L'viv: Vydavnytstvo L'vivs'koyi politekhniky. No. 793. s. 12-19.

Kordunyan O. P. 2009. Pryntsypy proportsionuvannya v arkhitekturnykh typakh hromads'kykh budivel' $i$ sporud Ukrayiny: avtoreferet dys. kand. arkh.: 18.00.02. L'viv. $22 \mathrm{~s}$.

T. Harashchak. 2017. Results of educational, experimental, research design of modern entertainment objects in Kielce by students of Lviv Politechnic University and Politechnica Swietokrzyska Kielce University of Technology. Housing Enviroment: composition in urban planning. Krakow. No. 21. p. 58.

Yu. Filipchuk. 2017. The architectural creation of theatrical and entertainment centers for children and young as a factor of increasting the attractiveness of cities in Ukraine. The example of the puppet theater in Kropyvnytcky. In: Joanna GillMastalerczyk, Politechnika Swietokryska, Zabudova na obszarach zurbanizowanych, zagrozonych oraz trudnyh. Kielce: Architektura 6. s. 56-66.

Z. V. Klymko. 2014. Vysvitlennya aktual'nosti doslidzhennya fenomenu stsenohrafiyi, yak skladovoyi teatral'noyi arkhitektury (na prykladi arkhitekturno - stsenohrafichnoyi tvorchosti Ye. M. Lysyka). B: M. M. D'omin. Suchasni problemy arkhitektury ta mistobuduvannya. Nauk. - tekhn. zbirnyk K.: KNUBA. Vyp. 36. s. 63-74.

Yu. Filipchuk. 2018. Rozvytok arkhitekturnykh idey v proektakh i budivlyakh teatral'no - vydovyshchnykh tsentriv dlya ditey ta molodi. In: Dyba Yu. R. Materialy dopovidey komisiyi arkhitektury ta mistobuduvannya NTSH pidhotovani do KHKHIKH naukovoyi sesiyi naukovoho tovarystva im. Shevchenka. L'viv. 28-29 bereznya 2018 r. s. 64-67.

Proskuryakov O. V. 2009. Pryntsypy arkhitektury spilky F. Fel'nera i H. Hel'mera i yikh rozvytok v Ukrayini: dys. kand. arkh. : 18.00.01. L'viv. $20 \mathrm{~s}$

Z. Klymko. 2016. Wplyw tworczosći scenografa Eugeniusza Lysyka na tworzenie teatralnej i kulturalno - edukacyinej architektury Lwowa. B: L. W. Kamoinka. Politechnika Swietokryska, Architektura zharmonizowana w przestrzeni miasta. Kielce: Architektura. s. 56-65.

K. Ianchuk. 2015. Conceptual educational projecting as a method of research and development known architecture and art masters. Housing Environment: composition in urban planning. Krakow. No. 14. p. 136-147.

Klymko Z. V. 2015. "Teatr" stsenohrafichnykh rishen' Ye. M. Lysyka na Praz'komu kvadriyenale 2015: pobudova prostoru, diyova orhanizatsiya i yikh oformlennya. In: Kulikov P. M. naukovo - vyrob. zbirnyk K.: KNUBA. Arkhitekturnyy visnyk. Vyp. 5. s. $57-67$.

Hovard Pamela, Drabek Pavel. 2019. What is scenography? New-York.: Routledge. p. XX-XXIV.

Kolchin B. A. 1985. Drevnyaya Rus': gorod, zamok, selo. M.: Nauka. s. 431.

Filipchuk M. 1998. Slov'yans'ki poselennya ukrayins'koho Prykarpattya u druhiy polovyni I tysyacholittya nashoyi ery. Stil's'ko i yoho okolytsi. Mykolayivshchyna. Zbirnyk naukovykh statey. T. S. L'viv: Instytut ukrayinoznavstva im. Kryp'yakevycha. NAN Ukrayiny. s. 80-104.

Rusanova I. P., Timoshchuk B. A. 1993. YAzycheskiye svyatilishcha drevnikh slavyan. M.: nauchn.-issled. arkh. tsentr “Arkhe". s. 7, 9, 11, 18, 19, 20-29.

\section{Віктор Проскуряков}

Професор кафедри дизайну архітектурного середовища

Національний університет “Львівська політехніка", Львів e-mail: Viktor.I.Proskuriakov@lpnu.ua orcid: 0000-0003-1022-8984

\section{ТВОРЕННЯ АРХІТЕКТУРИ ПЕРШОГО НАЦІОНАЛЬНОГО ТЕАТРАЛЬНОГО ПАВІЛЬЙОНУ ДЛЯ ВСЕСВІТНЬОЇ ВИСТАВКИ}

\footnotetext{
Анотація. Стаття присвячена аналізу Украйнських начіональних театральних павільйонів для всесвітніх виставок $і$ зокрема формуванню ідеї, з якої повстав проєкт архітектурного рішення $і$ спорудження Першого українського національного павільйону для Празького Квадріснале 2019 року, створений у Львівській архітектурній школі.

Таке завдання було абсолютно новим для викладачів і студентів, тому було вирішено розпочати пошуки архітектури иьього об'єкта задовго до червня 2019 року. Розпочати у семестрових проєктах, проєктах бакалаврських $i$ магістерських робіт. Розроблено багато иікавих проєктів, ідей, які були конкурентоздатними, але авторам не вдалося створити конструкиію $і$ простір, в яких би відображалися не тільки виставкова функиія, а $i$ генеза $i$ розвиток
} 
національної української культури, і зокрема театру. Дослідивши історичні матеріали і провівши аналіз сучасного проєктування, за ідею побудови простору дійової організаиії естетичного вирімення архітектури павільйону проф. В. Проскуряков прийняв споруду, в якій з прадавніх часів відбувалася "Купальська драма", що свойм виглядом нагадувала амфітеатр-віночок. Він після реконструкиії загального вигляду споруди і складових елементів розробив ескізи креслень, що стали базовими для сучасного театрального павільйону; підібрав сучасні матеріали конструктивних елементів; узгодив масштаб павільйону із параметрами відведеного для нього організаторами $P Q$ простору в "Промисловому палаиі". Упорядкувати креслення павільйону допомогли студенти стариих курсів В. Вовк $і$ А. Откидач, а виготовити масштабну модель павільйону - студенти М. Лопоша і Ю. Чолавін. Павільйон був доставлений $і$ змонтований у Празі у "Промисловому палаиіі" 6 червня, і покинув Квадрієнале ввечері 16 червня 2019.

Ключові слова: архітектурна ідея, театральні виставкові павільйони, Празьке квадрієнале. 